\title{
Increased photosynthesis compensates for shorter growing season in subarctic tundra -8 years of snow accumulation manipulations
}

\author{
Julia Bosiö • Christian Stiegler • Margareta Johansson • \\ Herbert N. Mbufong • Torben R. Christensen
}

Received: 30 July 2013 / Accepted: 8 September 2014 /Published online: 19 September 2014

C) The Author(s) 2014. This article is published with open access at Springerlink.com

\begin{abstract}
This study was initiated to analyze the effect of increased snow cover on plant photosynthesis in subarctic mires underlain by permafrost. Snow fences were used to increase the accumulation of snow on a subarctic permafrost mire in northern Sweden. By measuring reflected photosynthetic active radiation (PAR) the effect of snow thickness and associated delay of the start of the growing season was assessed in terms of absorbed PAR and estimated gross primary production (GPP). Six plots experienced increased snow accumulation and six plots were untreated. Incoming and reflected PAR was logged hourly from August 2010 to October 2013. In 2010 PAR measurements were coupled with flux chamber measurements to assess GPP and light use efficiency of the plots. The increased snow thickness prolonged the duration of the snow cover in spring. The delay of the growing season start in the treated plots was 18 days in 2011, 3 days in 2012 and 22 days in 2013. Results show higher PAR absorption, together with almost $35 \%$ higher light use efficiency, in treated plots compared to untreated plots. Estimations of GPP suggest that the loss in early season photosynthesis, due to the shortening of the growing season in the treatment plots, is well compensated for by the increased absorption of PAR and higher light use efficiency throughout the whole growing seasons. This compensation is likely to be explained by increased soil moisture and nutrients together with a shift in vegetation composition associated with the accelerated permafrost thaw in the treatment plots.
\end{abstract}

Electronic supplementary material The online version of this article (doi:10.1007/s10584-014-1247-4) contains supplementary material, which is available to authorized users.

J. Bosiö • C. Stiegler $(\bowtie) \cdot$ M. Johansson • T. R. Christensen

Department of Physical Geography and Ecosystem Science, Lund University, Lund, Sweden

e-mail: christian.stiegler@nateko.lu.se

M. Johansson

Royal Swedish Academy of Sciences, PO Box 50005, 10405 Stockholm, Sweden

H. N. Mbufong · T. R. Christensen

Department of Bioscience, Aarhus University, Roskilde, Denmark 


\section{Introduction}

Snow is one of the most important factors controlling vegetation and ecosystem functions in higher latitudes and alpine areas (Walker et al. 1993; Høye et al. 2007). The duration of snow cover and snow cover thickness directly govern fluxes of $\mathrm{CO}_{2}$ in plant communities (Grøndahl et al. 2007; Larsen et al. 2007; Nobrega and Grogan 2007; Grogan 2012) and in the colder regions, where the growing season is short, a few weeks of change in season length may have significant impact on phenology and ecosystem functions (Walker et al. 1999; Høye et al. 2007; Post et al. 2009; Elmendorf et al. 2012). Snow also serves as an insulating and protecting cover for many plants, as well as storage of water being released when snow melts in spring (Olsen et al. 2011).

Observations show that, although changes in snow depth and snow cover duration is not uniform over the Arctic (Brown and Mote 2009), winter snow depth increased in Scandinavia and Eurasia during the $20^{\text {th }}$ century (Callaghan et al. 2011). Projections made by General Circulation Models indicate that hydrological processes are expected to intensify with climate change (Christensen et al. 2007) and many regions in the Arctic and subarctic will experience an increase in snow water content (SWC) (Callaghan et al. 2011). Understanding of how temporal and spatial changes in snow patterns affect arctic and subarctic ecosystems is therefore crucial to better estimate the global carbon balance with a changing climate. In subarctic Fennoscandia, permafrost mires are currently subjected to climate related thawing (Åkerman and Johansson 2008; Callaghan et al. 2012) and shift in vegetational and hydrological patterns (Malmer et al. 2005; Bosiö et al. 2012). These changes exert a significant impact on atmospheric $\mathrm{CO}_{2}$ sink function and $\mathrm{CH}_{4}$ emissions (Christensen et al. 2004; Johansson et al. 2006) and on soil hydrologic dynamics (O'Donnell et al. 2012; Jorgenson et al. 2013).

Snow manipulation experiments have been carried out in various arctic, subarctic and alpine environments. Most common are snow fence manipulations where the snow is accumulated over the season, delaying the melt off, and snow removal and plot warming to simulate warmer climate and earlier snowmelt. A review over snow manipulation experiments in alpine and arctic environments show that the majority of the experiments run for 3 years or shorter, while some experiments (mainly focused on changes in species composition and phenology) run for longer time periods (4-32 years) (Wipf and Rixen 2010). Several studies have investigated productivity and plant growth (Walker et al. 1999; Welker et al. 2000; Chimner and Welker 2005; La Puma et al. 2007; Rixen et al. 2008). However, the results are not all conclusive: Plant biomass has shown to increase with increased snow cover (Walker et al. 1995, 1999; Wahren et al. 2005), but others report a decline in the overall ecosystem productivity due to delayed snowmelt and shortened growing season (Aurela et al. 2004; Grøndahl et al. 2007; Wipf and Rixen 2010). The effect of the snow manipulation experiments varied between a few decimeters to over two meters in increased snow depth. All the studies indicate no clear pattern with regard to the level of snow manipulation. Plant productivity and growth rates generally varied between species, showing negative response for grasses, positive response for forbs and no clear pattern for deciduous and evergreen dwarf shrubs (Wipf and Rixen 2010). Although changes in climate may have drastic effects upon the arctic tundra, the ecosystems response is slow in terms of equilibration and adaptation (Walker et al. 1999). It may take decades before the full impact of changes in the environmental conditions is visible. It is therefore essential to study the long term effects of increased winter snow cover on plant communities (Walker et al. 1999; Wipf and Rixen 2010).

A number of snow manipulation studies in the area surrounding Abisko have previously been reported (Grogan and Jonasson 2006; Larsen et al. 2007; Torp et al. 2010; Olofsson et al. 
2011). Enhanced snow depth and prolonged snow cover duration resulted in increased ecosystem respiration during late winter but had no effects during spring snowmelt (Larsen et al. 2007). Prolonged snow cover delayed plant phenology but favored plant growth and nutrient availability. Plant biomass decreased over the observation periods due to higher herbivore leaf damage and plant diseases (Larsen et al. 2007; Torp et al. 2010). After 3 years of snow manipulation at a lowland permafrost site Johansson et al. (2013) could observe increased soil wetness on the manipulated plots, especially after snowmelt. However, no statistically significant difference in plant species composition could be observed although the vegetation on the manipulated plots showed an increased "greening" by the end of the growing season. Carbon fluxes, measured during parts of the growing season in 2009 at the experimental plots, using manual closed chamber systems (unpublished), showed only a weak or non-significant correlation between the "greening" and the snow manipulation experiment.

Quantifying carbon fluxes of terrestrial ecosystems to predict current and future carbon sink activity has been a major challenge (Kicklighter et al. 2014). One commonly used method to estimate GPP of terrestrial biomes is the canopy light-use efficiency $(\varepsilon)$, defined as the ratio of GPP (or NPP) to absorbed light (Kergoat et al. 2008). Because of its theoretical basis and practicality, $\varepsilon$ provides an accurate description of terrestrial ecosystem productivity and is used at various spatial and temporal scales (Turner et al. 2002; Xiao et al. 2004; Bradford et al. 2005; Schwalm et al. 2006; Yuan et al. 2007).

\subsection{Aims and hypothesis}

Our main objective was to investigate how increased snow cover and prolonged snow cover duration affect plant photosynthesis in two subarctic tundra vegetation types: dry heath and moist tussock tundra. More specifically our aims were 1) to estimate the effect of the delayed date of snowmelt (DOSM) on the accumulated gross primary production (GPP) over the growing season for the two vegetation types and 2) to estimate to what extent areas subjected to several years of increased snow cover and prolonged snow cover duration, can compensate for the shortened growing season by increased photosynthesis. Based on previous visual observations, such as increased soil moisture and a greening effect of the vegetation, we hypothesize that the photosynthesis rate is higher in plots subjected to increased snow cover than plots under ambient snow cover conditions, and that the higher photosynthesis rate to some extent compensates for a shorter snow free period.

\section{Materials and methods}

\subsection{Study site}

We measured reflected photosynthetic active radiation (PAR) and carbon dioxide flux on Storflaket, a subarctic ombrotrophic mire underlain by permafrost located $6 \mathrm{~km}$ east of Abisko in northern Sweden $\left(68^{\circ} 20.8^{\prime} \mathrm{N}, 18^{\circ} 58.2^{\prime} \mathrm{E}, 383\right.$ m.a.s.l). The orographic effect of the surrounding Scandes mountains leaves the area in rain shadow, with as little as $362 \mathrm{~mm}$ precipitation per year, mean annual temperature is $+0.49^{\circ} \mathrm{C}$ for the period $2002-2011$ (official data from Abisko Scientific Research Station). The mire covers approximately 13 ha and is characterized by a $60-90 \mathrm{~cm}$ thick peat layer underlain by silty sediments (Klaminder et al. 2008; Åkerman and Johansson 2008). Because of underlying permafrost, the plant community is tundra-like, even if the surrounding is not strictly classified as tundra (Wielgolaski 1972). The dryer upraised palsa areas are characterized by dry heath vegetation with low growing 
dwarf shrubs, short sedges, bryophytes, lichens and barren soil. In hollows (thermokarst) and depressions, dominant vegetation consists of tussock-forming sedges and sphagnum mosses. In some areas dwarf shrubs, such as Betula nana, grow higher. The surrounding area is vegetated by birch and willow forest, tall shrubs and heath vegetation.

\subsection{Experimental setup}

\subsubsection{Snow manipulations}

Since 2005 the snow cover thickness has been manipulated by using snow fences (10 $\mathrm{m}$ long, $1 \mathrm{~m}$ high) to accumulate snow over six randomly selected experimental plots (+Snow). Snow fences were installed every year in September-October, perpendicular to the prevailing eastwest wind direction, and removed every year after snowmelt. Initially, snow accumulates on the west side and by the end of the snow season the effect of the snow manipulation covers approximately $20 \times 10 \mathrm{~m}$. Six control plots (Cont.) were selected randomly for comparison. For detailed description of the site and the experimental setup, see Johansson et al. (2013).

\subsubsection{PAR measurements}

Using the light use efficiency $(\varepsilon)$ model, GPP can directly be related to the amount of photosynthetic active radiation (PAR) absorbed by plants (APAR) (Monteith 1972, 1977) with the following equation (Monteith 1977):

$$
\mathrm{GPP}=\varepsilon \cdot \mathrm{APAR}
$$

where GPP is given in $\mu \mathrm{g} \mathrm{CO}_{2}-\mathrm{C} \mathrm{m}^{-2} \mathrm{~s}^{-1}$ and $\varepsilon$ is the light use efficiency parameter $\left(\mu \mathrm{g} \mathrm{CO}_{2}-\mathrm{C} \mu \mathrm{mol}^{-1}\right.$ ).

The amount of APAR can be derived from the incident light PAR $\left(\mu \mathrm{mol} \mathrm{m} \mathrm{m}^{-2} \mathrm{~s}^{-1}\right)$ and the fraction of PAR absorbed by vegetation (fAPAR) (Gobron and Verstraete 2009):

$$
\mathrm{APAR}=\mathrm{fAPAR} \cdot \mathrm{PAR}
$$

Photosynthetic photon flux density (PPFD) is a quantitative measure of PAR, i.e. the energy of the electromagnetic radiation in the interval $400-700 \mathrm{~nm}$, and fAPAR was calculated with the following equation:

$$
\mathrm{fAPAR}=\left(\mathrm{PPFD}_{\text {in }}-\mathrm{PPFD}_{\text {refl }}\right) / \mathrm{PPFD}_{\text {in }}
$$

where $\mathrm{PPFD}_{\text {in }}$ is the incident light and PPFD ${ }_{\text {refl }}$ is the reflected light, both in $\mu \mathrm{mol} \mathrm{m}{ }^{-2} \mathrm{~s}^{-1}$.

Assessing the photosynthetic activity by using PAR sensors is a non-intrusive method that allows high temporal resolution and requires little maintenance. In July 2010 Minikin QT loggers from EMS Brno were installed at $50 \mathrm{~cm}$ height in the middle of each plot to measure PPFD $_{\text {refl }}$ by the vegetated surface. On the treatment plots, the loggers were installed within a $5 \mathrm{~m}$ radius on the western side of the snow fence and one upward facing logger was installed to measure incident PPFD $\left(\right.$ PPFD $\left._{\text {in }}\right)$ for the site. Since all control (Cont.) and treatment (+Snow) plots are located within an area of less than 2 ha, one logger was considered enough to represent the incident light of all 12 plots. Measurements of incident PPFD from the nearby Abisko Scientific Research Station were used to validate the $\mathrm{PPFD}_{\text {in }} \operatorname{logger}$ at Storflaket. In 
2010 and 2011 PPFD $_{\text {refl }}$ was recorded and stored once per hour; in 2012 and 2013 PPFD $_{\text {refl }}$ was recorded once per minute and an hourly average was derived.

\subsubsection{Flux chamber measurements in 2010}

$\mathrm{CO}_{2}$ fluxes were measured manually using a PP Systems' gas analyzer (EGM-4) attached to a Plexiglas chamber. The chamber was equipped with a fan for air mixing during measurements. Net ecosystem exchange (NEE) was measured as the net exchange of $\mathrm{CO}_{2}$ between the uptake (mainly due to plant $\mathrm{CO}_{2}$ sequestration) and emissions (autotrophic and heterotrophic respiration). NEE was measured in a transparent chamber to quantify the effect of photosynthesis. Ecosystem dark respiration $\left(\mathrm{R}_{\mathrm{eco}}\right)$ was measured by shading the transparent chamber with a dark cloth. GPP was calculated as the difference between NEE and $\mathrm{R}_{\text {eco. The }}$ measurements were carried out on 15 days without precipitation between July and September. On each plot the measurements of NEE and $\mathrm{R}_{\text {eco }}$ were conducted between 10 and $14 \mathrm{~h}$ (CET) three times per day, from which daily means of NEE, $\mathrm{R}_{\text {eco }}$ and GPP were computed. Together with the chamber measurements, soil water content (SWC) and soil temperature was measured manually at $5 \mathrm{~cm}$ depth on three points per plot using a Theta Probe kit. Air temperature was not measured plot-wise but for the whole site during the chamber measurements. Results of NEE, $\mathrm{R}_{\mathrm{eco}}$, soil moisture, and soil and air temperature are presented in the appendix (App. 1; App. 2; App. 3).

\subsection{Data processing and statistical analysis}

Since vegetation covers the surface completely in the studied plots, with a moss layer closest to the ground, we assumed that all of the $\mathrm{PPFD}_{\text {in }}$ that was not reflected by the surface was absorbed by vegetation (Frolking et al. 1998; Huemmrich et al. 2010a). For each plot we calculated fAPAR separately in 1-h intervals throughout the whole growing season. In 2010, $\mathrm{PPFD}_{\text {in }}$ was taken from the nearby logger at Abisko Scientific Research Station. We assumed the growing season is equivalent to the period starting by the DOSM in spring and ending by the first day of snowfall in autumn.

Since DOSM differed between the control (Cont.) and the treatment plots (+Snow), DOSM was computed individually for Cont. $\left(\right.$ DOSM $\left._{C}\right)$ and + Snow $\left(\right.$ DOSM $\left._{S}\right)$. DOSM was defined as the date when all control and treatment plots were snow free. The high albedo of snow gives a clear signal in PPFD $_{\text {refl }}$ when snow is present or not. Therefore, DOSM was determined by the day when the maximum PPFD equaled or showed higher values of PPFD than the highest value of PPFD between 1 June and 31 August.

Hourly fAPAR ( fAPAR $_{h}$ ) was computed (Eq. 3) for each sensor separately, for three parts of the snow free season: Early season, peak season and late season. The early season was defined as the time period between DOSM until the daily average air temperature reached $>10.0^{\circ} \mathrm{C}$ within five consecutive days. The peak season was defined as the time period with daily average air temperatures $>10.0^{\circ} \mathrm{C}$, and the late season was defined as the time period when daily average air temperatures dropped below $10.0^{\circ} \mathrm{C}$ within five consecutive days until the first day of snowfall.

Since loggers were installed in the end of July 2010 , fAPAR $\mathrm{h}_{\mathrm{h}}$ could only be computed for the peak- and late season that year. Values of $\mathrm{PPFD}_{\text {in }}<1 \mu \mathrm{mol} \mathrm{m} \mathrm{m}^{-2} \mathrm{~s}^{-1}$ were filtered out, as they were regarded as nighttime; fAPAR $\mathrm{h}_{\mathrm{h}}<0$ was also excluded from the analysis. From $\mathrm{fAPAR}_{\mathrm{h}}$ we computed (plot-wise) daily mean fAPAR (fAPAR ${ }_{d}$ ). Due to sensor maintenance (15-17

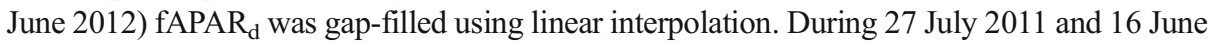


2012 data of one sensor at Cont. was removed from the analysis because it had fallen down (the exact date could be detected from a sharp increase in the reflected PAR).

Both PPFD $_{\text {refl }}$ and fAPAR $d$ of Cont. and + Snow were tested against normality. A nonparametric test (Mann-Whitney U-test) was performed to test the significance of the difference between control and treatment measurements.

\subsubsection{Estimation of $\varepsilon$ and GPP}

Plot-specific $\varepsilon$ values $\left(\varepsilon_{\text {plot }}\right)$ were estimated using $\mathrm{CO}_{2}$ flux measurements and APAR from the 15 days in 2010 . $\varepsilon_{\text {plot }}$ was computed for each plot by fitting a linear curve to the measured daily GPP and APAR values of each plot, assuming a linear relationship between GPP and APAR (Eq. 1), and that GPP is zero at $\mathrm{APAR}=0$. Since the chamber measurements were carried out between 10 and $14 \mathrm{~h}(\mathrm{CET})$, the daily APAR was computed as a mean of APARvalues during the same time period. $\varepsilon_{\text {plot }}$ was tested for correlation with day of year (DOY), soil water content (SWC) and soil temperature. Since only very weak and non-significant correlations were found (App. 1), we assumed $\varepsilon_{\text {plot }}$ to be relatively constant over the season. This assumption is supported by previous research, concluding that the light use efficiency differs among species and locations but is relatively fixed over the growing season, between years and even under manipulations of seasonal patterns in snow and temperature (Starr et al. 2008; Huemmrich et al. 2010a, b).

The photosynthetic capacity is assumed to quickly increases to its maximum to take advantage of the short growing season (Starr et al. 2008). We thus assumed $\varepsilon_{\text {plot }}$ to represent the specific vegetation, soil and water conditions of each plot, and used the $\varepsilon_{\text {plot }}$ to model hourly GPP $\left(\mathrm{GPP}_{\mathrm{h}}\right)$ from the hourly PAR measurements between 2010 and 2013. $\mathrm{GPP}_{\mathrm{h}}$ was computed plot wise for all years, according to Eqs. 1 and 2, where $\varepsilon$ equals $\varepsilon_{\text {plot }}$ for each plot, fAPAR equals the fAPAR $_{h}$ for each plot and PAR equals the hourly values of PPFD $_{\text {in }}$ for the site. Accumulated GPP (GPP accum) was computed for each plot by summing all $\mathrm{GPP}_{\mathrm{h}}(24$ values/day) for each part of the season. The plot where the sensor had fallen down in July 2011 was excluded from the GPP ${ }_{\text {accum }}$ computations, since $\mathrm{GPP}_{\mathrm{h}}$ could not be computed for most of the growing season in 2011 and parts of the growing season in 2012. The GPP accum was computed from the date of snowmelt until the first day of snowfall.

\section{Results}

\subsection{Snow and climate monitoring}

Since the installation of snow fences in the winter season 2005/06, the snow depth at + Snow was twice the depth of Cont. ( $20 \mathrm{~cm}$ and $10 \mathrm{~cm}$ respectively) (Johansson et al. 2013). Between 2011 and 2013 the thicker snow cover, caused by the snow fences hindering snow drift, prolonged the duration of snow cover in the treated plots. In 2011, DOSM was 10 May in + Snow compared to 22 April in Cont., i.e. a delay of 18 days. In 2012 the spring was late and snow melted rapidly in both Cont. and + Snow. DOSM was 18 May in + Snow compared to 15 May in Cont., hence a delay in DOSM in + Snow of only 3 days. In 2013, DOSM was 11 May in + Snow compared to 19 April in Cont., i.e. a delay of 22 days. Comparing the 3 years, the total length of the snow free season was 193 days for Cont. (175 days for + Snow) in 2011, 162 (159) days in 2012 and 178 (156) days in 2013.

The snow free season in 2013 was warmer than the two preceding years. From the early season until end of late season the daily mean temperature was $9.0^{\circ} \mathrm{C}$ in $2013,7.0^{\circ} \mathrm{C}$ in 2012 
and $8.8^{\circ} \mathrm{C}$ in 2011.2011 was drier than the following years with accumulated precipitation of $228.4 \mathrm{~mm}$, compared to $262.4 \mathrm{~mm}$ in 2012 and $232.3 \mathrm{~mm}$ in 2013 . The accumulated winter precipitation (precipitation from the day of first snow in the preceding year until DOSM $_{C}$ ) was higher in the winter season 2010/11 (140.8 $\mathrm{mm}$ ) than in 2011/12 (116.2 mm) and in 2012/13 $(81.9 \mathrm{~mm})$. The maximum snow depth (precipitation and snow depth data from the Abisko Scientific Research Station, 6 km west of the site) in 2011 and 2012 was 66 and $54 \mathrm{~cm}$ respectively; In 2013 the maximum snow depth reached $55 \mathrm{~cm}$. Due to wind drift, the ambient snow depth at the site (i.e. snow depth in control plots) is lower $(\sim 10 \mathrm{~cm})$.

\subsection{Carbon flux measurements in 2010}

The chamber flux measurements showed a significant $(p<0.001)$ difference in GPP between Cont. and + Snow. GPP was on average $57 \%$ higher (medians compared) in + Snow than in Cont., ranging between 0.04 and $0.28 \mathrm{~g} \mathrm{CO}_{2}-\mathrm{C} \mathrm{m}^{-2} \mathrm{~h}^{-1}$ for + Snow and 0.02-0.20 $\mathrm{g} \mathrm{CO}_{2^{-}}$ $\mathrm{C} \mathrm{m}^{-2} \mathrm{~h}^{-1}$ for Cont. from peak season (mid of July) to late season (end of September). The $\varepsilon_{\mathrm{d}}$ parameter computed from $\mathrm{GPP}_{\mathrm{d}}$ and APAR measurements in 2010, showed a significant $(p<0.001)$ difference in $\varepsilon_{\mathrm{d}}$ between + Snow and Cont. (Fig. 1). $\varepsilon_{\text {plot }}$ was on average $0.0486 \mu \mathrm{g} \mathrm{CO}_{2}-\mathrm{C}_{\mu \mathrm{mol}^{-1}}$ in Cont. and $0.0692 \mu \mathrm{g} \mathrm{CO}_{2}-\mathrm{C}_{\mu \mathrm{mol}}{ }^{-1}$ in + Snow, i.e. $0.0206 \mu \mathrm{g} \mathrm{CO}_{2}-\mathrm{C} \mu \mathrm{mol}^{-1}$ higher in + Snow than in Cont. (App. 2). No significant trend could be seen in $\varepsilon_{\text {plot }}$ with changing DOY over the snow free period (App. 1), thus we assumed $\varepsilon_{\text {plot }}$ to be constant over the growing season.

\section{3 fAPAR}

Median + Snow fAPAR $_{d}$ in late season is strongly significantly $(p<0.001)$ lower in 2013 than in 2012 and 2011. +Snow fAPAR during peak season is highest in 2011 whereas no clear difference between median $\mathrm{fAPAR}_{\mathrm{d}}$ was observed in the other years. In the early season, differences in median $\mathrm{fAPAR}_{\mathrm{d}}$ between years are small (Fig. 2).

Cont. shows a similar pattern for late season, with highest fAPAR $\mathrm{f}_{\mathrm{d}} 2011$ and 2012. During peak season no pronounced difference in fAPAR ${ }_{d}$ was observed in 2011 and 2013. In

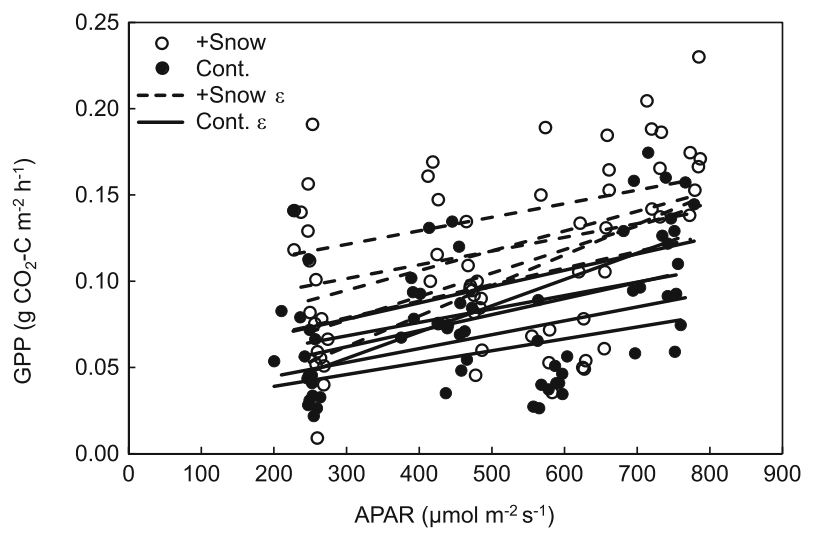

Fig. 1 Relationship between daytime GPP and APAR measured in 2010. The slope of the linear relationship between APAR and GPP represents $\varepsilon_{\text {plot }}$ for control plots (filled circles, solid lines) and treatment plots (empty circles, dashed lines) 

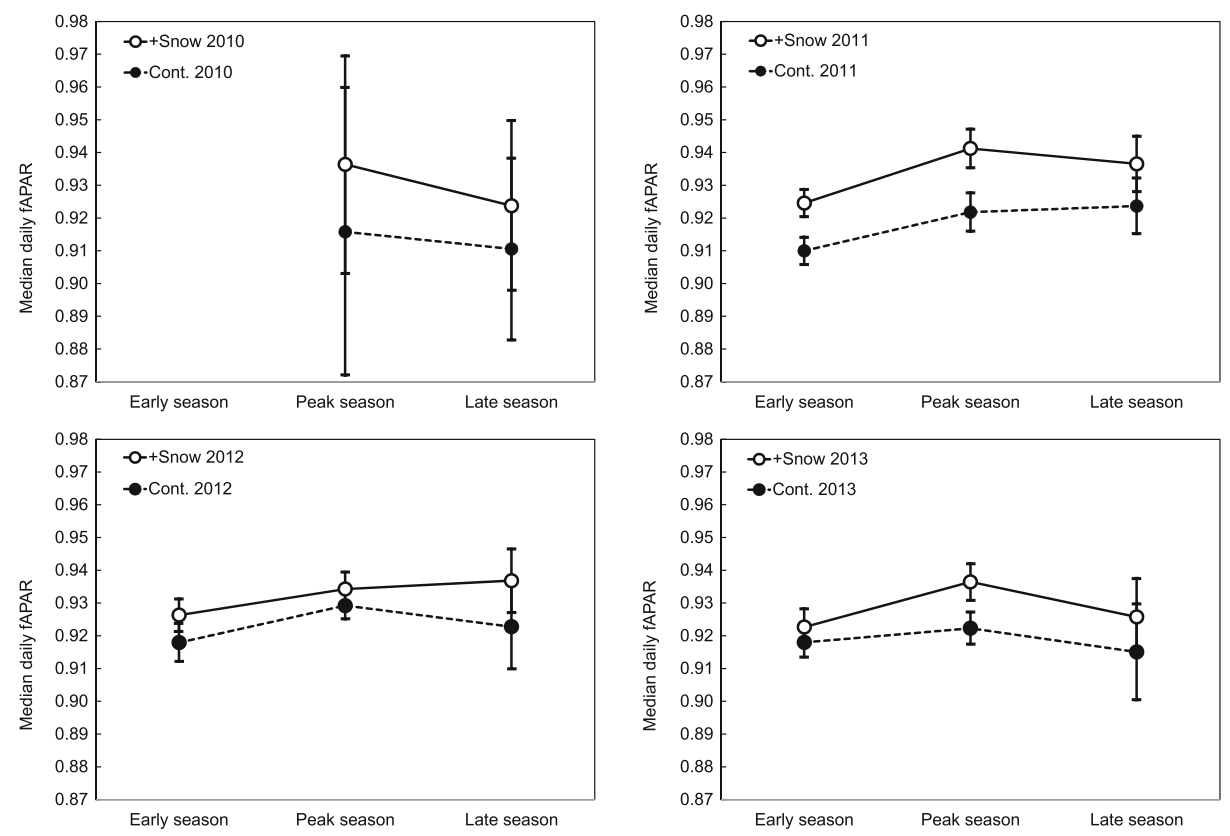

Fig. 2 Median daily fAPAR for early, peak and late season from 2010 to 2013. Filled circles indicate median values for control plots, empty circles indicate treatment plots. Bars show the median absolute deviation (MAD)

early season, fAPAR is lowest in 2011, for 2013 and 2012 no clear difference was observed (Fig. 2).

For 2011-2013 the difference in $\mathrm{fAPAR}_{d}$ between + Snow and Cont. $(\triangle \mathrm{fAPAR}=$ median fAPAR $_{\mathrm{d}, \mathrm{T}}-$ median fAPAR $\left.\mathrm{d}, \mathrm{C}\right)$ was strongly significant $(p<0.001)$, where median fAPAR $_{\mathrm{d}}$ for + Snow is generally higher than for Cont. On average, fAPAR $\mathrm{d}_{\mathrm{d}}$ is $1.3 \%$ higher in + Snow than in Cont. with a strong significance through all parts of the seasons and years. The difference is most pronounced during peak season $(1.6 \%)$ and late season $(1.4 \%)$, whereas during early season the difference is $1.0 \%$.

Mid-day (10-14 h) fAPAR in 2010, to estimate the seasonal GPP, showed significant difference $(p<0.001)$ between + Snow and Cont., where mean fAPAR was 0.90 in Cont. and 0.93 in + Snow.

\subsection{Estimated seasonal GPP}

Figure 3 illustrates the accumulated GPP over the seasons for Cont. and + Snow during 2010 2013. The modeled GPP accum showed that a delayed start of the growing season in + Snow, compared to Cont., results in a lower $\mathrm{GPP}_{\text {accum }}$ in + Snow (medians compared). The difference in $\mathrm{GPP}_{\text {accum }}$ is strongest in 2011 and 2013, when average delay of the growing season between + Snow and Cont. was 20 days. In 2012 the delay was 3 days, resulting in higher GPP $_{\text {accum }}$ in + Snow.

For the peak season the modeled $\mathrm{GPP}_{\text {accum }}$ is, on average, $14.9 \mathrm{~g} \mathrm{C} \mathrm{m}^{-2}$ higher in + Snow than in Cont. (2011-2013). GPP accum for the same years in the late season is, on average, $2.5 \mathrm{~g} \mathrm{C} \mathrm{m}^{-2}$ higher in + Snow than in Cont. Compared to 2011 and 2013, lower average air temperatures during the growing season in 2012 resulted in lower total GPP $_{\text {accum }}$ for both + 

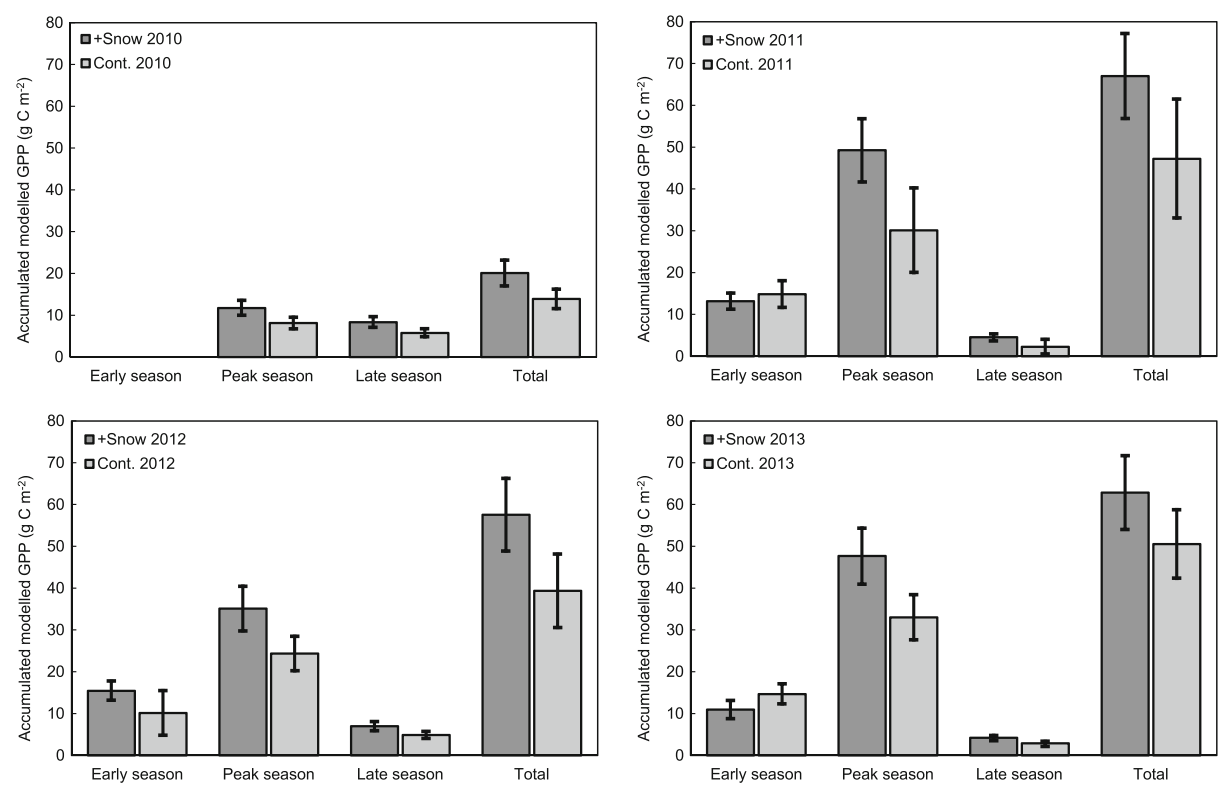

Fig. 3 Modeled $\mathrm{GPP}_{\text {accum }}$ for control (Cont.) and treatment (+Snow) plots for early, peak and late season from 2010 to 2013. Bars show the standard deviation

Snow and Cont. Although the measurement period in 2010 is reduced due to the late start of our measurements, $\mathrm{GPP}_{\mathrm{accum}}$ in + Snow is higher than in Cont. for both peak and late season.

\section{Discussion}

\subsection{Observed differences between control and treatment plots}

Measured fAPAR and estimated GPP showed significant differences between + Snow and Cont., where both fAPAR and accumulated GPP over the growing season, was higher in + Snow than in Cont. Previous studies on snow-vegetation interaction have observed similar effects (Walker et al. 1995, 1999; Wahren et al. 2005), although increased plant growth may be a short-term response (Walker et al. 1995). Several studies report no (Starr et al. 2008) or even negative (Aurela et al. 2004; Larsen et al. 2007; Torp et al. 2010; Wipf and Rixen 2010) effect on plant growth or photosynthesis from increased snow cover or delayed snowmelt. We conclude that our plots with experimentally increased snow cover still benefit compared to plots under ambient snow conditions.

The accumulation of snow affects the abiotic conditions both directly and indirectly, e.g. it acts as insulating layer during winter, preventing soil temperatures to drop as low as under ambient conditions. Increased snow depth has induced permafrost thawing and associated ground subsidence in + Snow with water table closer to (and sometimes above) ground level and thicker active layer (Johansson et al. 2013). In tundra regions, where plants are adapted to short growing seasons but often are moisture limited (Keuper et al. 2012a), the timing of snowmelt and the availability of water during the peak growing season are important factors regulating plant growth and annual carbon balance (Aurela et al. 2004). In line with our observations from Storflaket, increased productivity due to permafrost thawing was reported 
from Alaskan tundra sites (Trucco et al. 2012) and from five peatland sites in northern subarctic Sweden (Keuper et al 2012b).

The insulation effect of the snow and thicker active layer exposes larger volumes of unfrozen organic soil to microbial decomposition. The thicker active layer allows roots to penetrate deeper into the soil substrate and thus increases nutrient uptake (Schimel et al. 2004). According to Johansson et al. (2013) the treated plots at Storflaket have significantly higher soil temperatures than control plots at both 15 and $50 \mathrm{~cm}$ depth during winter (NovemberApril). We hypothesize that the combined effects of increased moisture and temperature promotes nutrient availability and graminoid growth.

\subsection{Interannual variability}

When comparing our fAPAR and GPP measurements between the years 2011 and 2013 and vegetation analysis from Johansson et al. (2013) the picture becomes more complex. In + Snow they observed a dominance of Eriophorum vaginatum, with higher tillers compared to Cont., and a pronounced greening at the end of the summer but no statistically significant change in the abundance of plant functional types between Cont. and + Snow.

In 2012, snow melted almost a month later than in 2011 and 2013 (Cont. compared). The modeled accumulated GPP was lower for both Cont. and + Snow in 2012 than in 2011 and 2013, likely due to the overall shorter season. The lower cumulative GPP in + Snow in 2012 may also be an effect of climate conditions during that growing season. +Snow appears to overcompensate for the shorter growing season but the climate conditions were less favorable that year by showing lower peak season fAPAR in 2012 than in the other years. However, Cont. did not seem to be negatively affected by the colder and wetter weather in 2012 with significantly highest fAPAR in 2012 during early and peak season, i.e. the periods of most importance for production (when temperature and light availability is at its highest). This indicates that, in spite of a colder and wetter growing season, the delayed snowmelt promoted plant growth in Cont. but it was not enough to offset the delayed snowmelt and subsequent shortening of the growing season. This suggests that the overall species composition in Cont. is better adapted to colder growing season temperatures. Vegetation in Cont., where soil is drier than in + Snow (App. 3), benefits from more precipitation. On the other hand, vegetation in + Snow is not limited by moisture and is likely to be favored by higher growing season temperature (as in 2011 and 2013) rather than wet and cold growing season conditions as in 2012. Our results indicate that interannual variability, i.e. snow cover duration and length of the growing season, primarily affects the cumulative GPP. Photosynthetic capacity of the vegetation is mainly controlled by the indirect, long-term effects such as hydrological changes, nutrient availability, diseases, and shifts in species composition (Larsen et al. 2007; Torp et al. 2010). According to Walker et al. (1999) the long term effect of climatic changes depend greatly on the species adaptation ability. Therefore, increased snow cover and delayed snowmelt may favor species such as Betula nana and Eriophorum vaginatum, with high photosynthetic capacity in relation to evergreen shrubs (Bigger and Oechel 1982; Starr et al. 2008), and higher potential to take advantage of increased soil temperature, soil moisture and nutrient availability (Bigger and Oechel 1982; Shaver et al. 1986; Schimel et al. 2004; Wahren et al. 2005; Starr et al. 2008).

\subsection{Potential feedback mechanisms}

In spite of increased GPP, the observed changes in plant community structure towards a dominance of graminoids (Johansson et al. 2013) may have a large impact on the regions carbon balance and act as a positive feedback to climate. Existing lowland permafrost in 
northern Fennoscandia is under severe threat of disappearance with projected climate change (Akerman and Johansson 2008), and large areas of predominantly dry hummock vegetation is facing a shift towards wetter conditions and an increase in graminoid vegetation (Bosiö et al. 2012). If the thawed peatlands remains waterlogged for long periods of the year the increased carbon uptake through photosynthesis is offset by increased methane emissions, with much stronger global warming potential on a 100 year time frame (Bäckstrand et al. 2010; Jackowicz-Korczynski et al. 2010).

\subsection{Uncertainties and future research}

In previous studies, it has been shown that the light use efficiency is dependent on a number of variables such as temperature, soil type, soil moisture, nutrient availability, plant type, growth state, plant age, and plant health (Prince 1991; Potter et al. 1993; Ruimy et al. 1994; Brogaard et al. 2005; Alton et al. 2007). Further, the light use efficiency parameter varies with time of the year and location but shows little interannual variation (Turner et al. 2002; Schwalm et al. 2006; Connolly et al. 2009). Since the light use efficiency for our study was estimated from field measurements made during mid- and late part of the season, we have no indication of how $\varepsilon$ varies in the very beginning of the season. Starr et al. (2008) argues that since interannual variations in photosynthetic capacity is small for most species, it is more important to focus on the species composition and total photosynthetic leaf area than variations within species-level when estimating the effects of climate change on carbon assimilation. Huemmrich et al. (2010a, b) also found that the light use efficiency parameter is constant throughout the growing season, but varies between species and that soil moisture was the key variable in regulating the carbon assimilation in tundra environment. We assumed that $\varepsilon_{\text {plot }}$ was constant over the whole growing season and may thus have overestimated $\varepsilon_{\text {plot }}$ during the early season. Since $\varepsilon_{\text {plot }}$ shows only very weak correlation with DOY, soil moisture and soil temperature (App. 1), we assume this overestimation of $\varepsilon_{\text {plot }}$ during the early season as negligible.

Previous studies have shown that date of snowmelt is a good predictor for determining growing season productivity (Aurela et al. 2004; Grøndahl et al. 2007; Wipf and Rixen 2010). Nevertheless, interactions between date of snowmelt and plant productivity are complex. Our measurements suggest that a thicker snow cover initiates potential feedback effects such as changes in soil hydrology. The increase in soil moisture alters plant growth and results in higher fAPAR and GPP. In contrast to theories suggesting that increased growth due to prolonged snow cover is a transitional short term effect (Walker et al. 1995), we hypothesize that this effect is due to shift in vegetation community as plants adapt to changed conditions, and hence an effect that will last for as long as the snow cover remains thicker than under ambient conditions.

Acknowledgments This work was supported by a FORMAS funded Climate Adaptation Project, EU-CarboExtreme, The Royal Swedish Academy of Science and the VR funded Linnéus Environment LUCCI. It also forms part of the Nordic Centre of Excellence DEFROST.

Open Access This article is distributed under the terms of the Creative Commons Attribution License which permits any use, distribution, and reproduction in any medium, provided the original author(s) and the source are credited. 


\section{References}

Åkerman HJ, Johansson M (2008) Thawing permafrost and thicker active layers in sub-arctic Sweden. Permafr Periglac Process 19(3):279-292. doi:10.1002/ppp.626

Alton PB, North PR, Los SO (2007) The impact of diffuse sunlight on canopy light-use efficiency, gross photosynthetic product and net ecosystem exchange in three forest biomes. Glob Chang Biol 13:776-787. doi:10.1111/j.1365-2486.2007.01316.x

Aurela M, Laurila T, Tuovinen J-P (2004) The timing of snow melt controls the annual $\mathrm{CO}_{2}$ balance in a subarctic fen. Geophys Res Lett 31(16), L16119. doi:10.1029/2004g1020315

Bäckstrand K, Crill PM, Jackowicz-Korczynski M, Mastepanov M, Christensen TR, Bastviken D (2010) Annual carbon gas budget for a subarctic peatland, Northern Sweden. Biogeosciences 7(1):95-108

Bigger CM, Oechel WC (1982) Nutrient effect on maximum photosynthesis in arctic plants. Holarct Ecol 5(2): 158-163. doi: $10.2307 / 3682452$

Bosiö J, Johansson M, Callaghan TV, Johansen B, Christensen TR (2012) Future vegetation changes in thawing subarctic mires and implications for greenhouse gas exchange - a regional assessment. Clim Chang 115(2): 379-398. doi:10.1007/s10584-012-0445-1

Bradford JB, Hicke JA, Lauenroth WK (2005) The relative importance of light-use efficiency modifications from environmental conditions and cultivation for estimation of large-scale net primary productivity. Remote Sens Environ 96:246-255. doi:10.1016/j.rse.2005.02.013

Brogaard S, Runnström M, Seaquist JW (2005) Primary production of Inner Mongolia, China, between 1982 and 1999 estimated by a satellite data-driven light use efficiency model. Glob Planet Chang 45(4):313-332

Brown RD, Mote PW (2009) The response of northern hemisphere snow cover to a changing climate. J Clim 22: 2124-2145

Callaghan TV, Johansson M, Brown R et al (2011) The changing face of arctic snow cover: a synthesis of observed and projected changes. AMBIO 40(1):17-31. doi:10.1007/s13280-011-0212-y

Callaghan TV, Jonasson C, Thierfelder T et al (2012) Ecosystem change and stability over multiple decades in the Swedish subarctic: complex processes and multiple drivers. Phil Trans R Soc B 368:20120488

Chimner RA, Welker JM (2005) Ecosystem respiration responses to experimental manipulations of winter and summer precipitation in a Mixedgrass Prairie, WY, USA. Biogeochemistry 73:257-270. doi:10.1007/ s10533-004-1989-6

Christensen TR, Johansson T, Åkerman HJ et al (2004) Thawing sub-arctic permafrost: effects on vegetation and methane emissions. Geophys Res Lett 31, L04501. doi:10.1029/2003GL018680

Christensen JH, Hewitson B, Busuioc A et al (2007) Regional climate projections. In: Solomon S, Qin D, Manning M et al (eds) Climate change 2007: the physical science basis. Contribution of Working Group I to the Fourth Assessment Report of the Intergovernmental Panel on Climate Change. Intergovernmental Panel on Climate Change, Cambridge, pp 847-940

Connolly J, Roulet NT, Seaquist JW et al (2009) Using MODIS derived fPAR with ground based flux tower measurements to derive the light use efficiency for two Canadian peatlands. Biogeosciences 6(2):225-234

Elmendorf SC, Henry GHR, Hollister RD et al (2012) Global assessment of experimental climate warming on tundra vegetation: heterogeneity over space and time. Ecol Lett 15(2):164-175. doi:10.1111/j.1461-0248.2011.01716.x

Frolking SE, Bubier JL, Moore TR et al (1998) Relationship between ecosystem productivity and photosynthetically active radiation for northern peatllands. Glob Biogeochem Cycles 12(1):115-126

Gobron N, Verstraete MM (2009) FAPAR. Fraction of absorbed photosynthetically active radiation. Food and Agriculture Organization of the United Nations (FAO). http://www.fao.org/gtos/doc/ECVs/T10/T10.pdf. Accessed 12 June 2014

Grogan P (2012) Cold season respiration across a low arctic landscape: the influence of vegetation type, snow depth, and interannual climatic variation. Arct Antarct Alp Res 44(4):446-456

Grogan P, Jonasson S (2006) Ecosystem $\mathrm{CO}_{2}$ production during winter in a Swedish subarctic region: the relative importance of climate and vegetation type. Glob Chang Biol 12(8):1479-1496

Grøndahl L, Friborg T, Soegaard H (2007) Temperature and snow-melt controls on interannual variability in carbon exchange in the high Arctic. Theor Appl Climatol 88(1):111-125

Høye TT, Post E, Meltofte H, Schmidt NM, Forchhammer MC (2007) Rapid advancement of spring in the High Arctic. Rapid Adv Spring High Arctic 17(12):R449-R451. doi:10.1016/j.cub.2007.04.047

Huemmrich KF, Gamon JA, Tweedie CE et al (2010a) Remote sensing of tundra gross ecosystem productivity and light use efficiency under varying temperature and moisture conditions. Remote Sens Environ 114(3): 481-489

Huemmrich KF, Kinoshita G, Gamon JA, Houston S, Kwon H, Oechel WC (2010b) Tundra carbon balance under varying temperature and moisture regimes. J Geophys Res 115:G00I02. doi:10.1029/ 2009jg001237 
Jackowicz-Korczynski M, Christensen TR, Bäckstrand K, Crill P, Friborg T, Mastepanov M, Ström L (2010) Annual cycle of methane emission from a subarctic peatland. J Geophys Res Biogeosci 115:10. doi:10.1029/ 2008jg000913

Johansson T, Malmer N, Crill PM et al (2006) Decadal vegetation changes in a northern peatland, greenhouse gas fluxes and net radiative forcing. Glob Chang Biol 12:2352-2369. doi:10.1111/j.1365-2486.2006.01267.x

Johansson M, Callaghan TV, Bosiö J, Åkerman HJ, Jackowicz-Korczynski M, Christensen TR (2013) Rapid responses of permafrost and vegetation to experimentally increased snow cover in sub-arctic Sweden. Environ Res Lett 8:035025. doi:10.1088/1748-9326/8/3/035025

Jorgenson MT, Harden J, Kanevskiy M et al (2013) Reorganization of vegetation, hydrology and soil carbon after permafrost degradation across heterogeneous boreal landscapes. Environ Res Lett 8:035017

Kergoat L, Lafont S, Arneth A et al (2008) Nitrogen controls plant canopy light-use efficiency in temperate and boreal ecosystems. J Geophys Res 113, G04017. doi:10.1029/2007JG000676

Keuper F, Parmentier F-J, Blok D et al. (2012a) Tundra in the Rain: Differential vegetation responses to three years of experimentally doubled summer precipitation in Siberian shrub and Swedish bog tundra. AMBIO 41(Supplement 3). doi:10.1007/s13280-012-0305-2

Keuper F, van Bodegom PM, Dorrepaal E et al (2012b) A frozen feast: thawing permafrost increases plant-available nitrogen in subarctic peatlands. Glob Chang Biol 18:1998-2007. doi:10.1111/j.1365-2486.2012.02663.x

Kicklighter DW, Cai Y, Zhuang Q et al (2014) Potential influence of climate-induced vegetation shifts on future land use and associated land carbon fluxes in Northern Eurasia. Environ Res Lett 9:035004. doi:10.1088/ $1748-9326 / 9 / 3 / 035004$

Klaminder J, Yoo K, Rydberg J, Giesler R (2008) An explorative study of mercury export from a thawing palsa mire. J Geophys Res Biogeosci 113(G4)

La Puma IP, Philippi TE, Oberbauer SF (2007) Relating NDVI to ecosystem $\mathrm{CO}_{2}$ exchange patterns in response to season length and soil warming manipulations in arctic Alaska. Remote Sens Environ 109:225-236

Larsen KS, Grogan P, Jonasson S, Michelsen A (2007) Respiration and microbial dynamics in two subarctic ecosystems during winter and spring thaw: effects of increased snow depth. Arct Antarct Alp Res 39(2):268-276

Malmer N, Johansson T, Olsrud M, Christensen TR (2005) Vegetation, climatic changes and net carbon sequestration in a North-Scandinavian subarctic mire over 30 years. Glob Chang Biol 11:1895-1909. doi: 10.1111/j.1365-2486.2005.01042.x

Monteith JL (1972) Solar radiation and productivity in tropical ecosystems. J Appl Ecol 9(3):747-766

Monteith JL (1977) Climate and the efficiency of crop production in Britain [and discussion]. Philos Trans R Soc Lond Biol Sci 281(980):277-294. doi:10.1098/rstb.1977.0140

Nobrega S, Grogan P (2007) Deeper snow enhances winter respiration from both plant-associated and bulk soil carbon pools in birch hummock tundra. Ecosystems 10:419-431. doi:10.1007/s10021-007-9033-z

O'Donnell JA, Jorgenson MT, Harden JW et al (2012) The effects of permafrost thaw on soil hydrologic, thermal, and carbon dynamics in an Alaskan peatland. Ecosystems 15:213-229. doi:10.1007/s10021-011-9504-0

Olofsson J, Ericson L, Torp M, Stark S, Baxter R (2011) Carbon balance of Arctic tundra under increased snow cover mediated by plant pathogen. Nat Clim Chang 1:220-223. doi:10.1038/nclimate1142

Olsen MS, Callaghan TV, Reist JD et al (2011) The changing arctic cryosphere and likely consequences: an overview. AMBIO 40(1):111-118. doi:10.1007/s13280-011-0220-y

Post E, Forchhammer MC, Bret-Harte MS et al (2009) Ecological dynamics across the Arctic associated with recent climate change. Science 325(5946):1355-1358. doi:10.1126/science.1173113

Potter CS, Randerson JT, Field CB, Matson PA et al (1993) Terrestrial ecosystem production: a process model based on global satellite and surface data. Glob Biogeochem Cycles 7:811-841

Prince SD (1991) Satellite remote sensing of primary production: comparison of results for Sahelian grasslands 1981-1988. Int J Remote Sens 12(6):1301-1312

Rixen C, Freppaz M, Stoeckli Vet al (2008) Altered snow denisty and chemistry change soil nitrogen mineralization and plant growth. Arct Antarct Alp Res 40(3):568-575. doi:10.1657/1523-0430(07-044)[RIXEN]2.0.CO;2

Ruimy A, Saugier B, Dedieu G (1994) Methodology for the estimation of terrestrial net primary production from remotely sensed data. J Geophys Res 99:5263-5283

Schimel JP, Bilbrough C, Welker JM (2004) Increased snow depth affects microbial activity and nitrogen mineralization in two Arctic tundra communities. Soil Biol Biochem 36(2):217-227

Schwalm CR, Black AT, Amiro BD et al (2006) Photosynthetic light use efficiency of three biomes across an east-west continental-scale transect in Canada. Agric For Meteorol 140:269-286. doi:10.1016/j.agrformet. 2006.06.010

Shaver GR, Chapin FS III, Gartner BL (1986) Factors limiting seasonal growth and peak biomass accumulation in Eriophorum vaginatum in Alaskan tussock tundra. J Ecol 74(1):257-278. doi:10.2307/2260362

Starr G, Oberbauer S, Ahlquist L (2008) The photosynthetic response of Alaskan tundra plants to increased season length and soil warming. Arct Antarct Alp Res 40(1):181-191. doi:10.1657/1523-0430(06-015) [starr]2.0.co;2 
Torp M, Witzell J, Baxter R, Olofsson J (2010) The effect of snow on plant chemistry and invertetrage herbivory: experimental manipulations along a natural snow gradient. Ecosystems 13:741-751. doi:10.1007/s10021010-9351-4

Trucco C, Schuur EAG, Natali SM, Belshe EF, Bracho R, Vogel J (2012) Seven-year trends of $\mathrm{CO}_{2}$ exchange in a tundra ecosystem affected by long-term permafrost thaw. J Geophys Res Biogeosci 117(G2):n/a-n/a. doi: 10.1029/2011JG001907

Turner DP, Gower ST, Cohen WB et al (2002) Effects of spatial variability in light use efficiency on satellite based NPP monitoring. Remote Sens Environ 80:397-405

Wahren CHA, Walker MD, Bret-Harte MS (2005) Vegetation responses in Alaskan arctic tundra after 8 years of a summer warming and winter snow manipulation experiment. Glob Chang Biol 11(4):537-552. doi:10.1111/ j.1365-2486.2005.00927.x

Walker DA, Halfpenny JC, Walker MD, Wessman CA (1993) Long-term studies of snow-vegetation interactions. Bioscience 43(5):287-301. doi:10.2307/1312061

Walker MD, Ingersoll RC, Webber PJ (1995) Effects of interannual climate variation on phenology and growth of two alpine forbs. Ecology 76(4):1067-1083. doi:10.2307/1940916

Walker MD, Walker DA, Welker JM et al (1999) Long-term experimental manipulation of winter snow regime and summer temperature in arctic and alpine tundra. Hydrol Process 13(14-15):2315-2330. doi:10.1002/ (SICI)1099-1085(199910)13:14/15<2315::AID-HYP888>3.0.CO;2-A

Welker JM, Fahnestock JT, Jones MH (2000) Annual $\mathrm{CO}_{2}$ flux in dry and moist arctic tundra: field responses to increases in summer temperatures and winter snow depth. Clim Chang 44(1-2):139-150. doi:10.1023/ a:1005555012742

Wielgolaski FE (1972) Vegetation types and plant biomass in tundra. Arct Alp Res 4(4):291-305

Wipf S, Rixen C (2010) A review of snow manipulation experiments in Arctic and alpine tundra ecosystems. Polar Res 29(1):95-109. doi:10.1111/j.1751-8369.2010.00153.x

Xiao X, Zhang Q, Braswell B et al (2004) Modeling gross primary production of temperate deciduous broadleaf forest using satellite images and climate data. Remote Sens Environ 91:256-270. doi:10.1016/j.rse.2004.03.010

Yuan W, Liu S, Zhou G et al (2007) Deriving a light use efficiency model from eddy covariance flux data for predicting daily gross primary production across biomes. Agric For Meteorol 143:189-207. doi:10.1016/j. agrformet.2006.12.001 